\title{
PENGARUH MODEL PEMBELAJARAN KOOPERATIF TIPE THINK TALK WRITE (TTW) TERHADAP KEMAMPUAN MENULIS PUISI SISWA KELAS VIII SMP SWASTA NASRANI 3 TAHUN PELAJARAN 2019/2020
}

\author{
Erikson Sihombing, Anisah \\ Fakultas Keguruan dan Ilmu Pendidikan \\ Universitas Prima Indonesia \\ Email: ericksonsihombing98@gmail.com, anni83sah@gmail.com
}

\begin{abstract}
Abstrak
Penelitian ini bertujuan untuk mengetahui: Pengaruh Model Pembelajaran Kooperatif Tipe Think Talk Write (TTW) Terhadap Kemampuan Menulis Puisi Siswa Kelas VIII SMP Swasta Nasrani 3. Penelitian ini merupakan penelitian quasi eksperimen. Populasi penelitian ini adalah siswa Kelas VIII SMP Swasta Nasrani 3. Pemilihan sampel dilakukan secara random dengan mengacak kelas. Instrumen yang digunakan terdiri dari tes Kemampuan Menulis Puisi siswa. Hasil penelitian menunjukkan dari skor ratarata skor kemampuan menulis puisi siswa yang dibelajarkan dengan model pembelajaran TTW dengan rata-rata dikoreksi $\bar{Y}_{(\mathrm{res}) \mathrm{Al}}=28,84$ sedangkan skor kemampuan menulis puisi siswa yang dibelajarkan dengan model pembelajaran ekspositori dengan rata-rata dikoreksi $\bar{Y}_{(\mathrm{res}) \mathrm{A} 2}=25,47$, sedangkan $\mathrm{t}_{\text {tabel }}=$ 2.036. karena $t_{\text {hitung }}>t_{\text {tabel }}$ maka $H_{0}$ ditolak. Dengan demikian disimpulkan bahwa terdapat perbedaan kemampuan menulis puisi antara siswa yang dibelajarkan dengan model pembelajaran TTW $\left(\mathrm{A}_{1}\right)$ dan siswa yang dibelajarkan dengan model pembelajaran ekspositori $\left(\mathrm{A}_{2}\right)$.
\end{abstract}

Kata Kunci: pembelajaran TTW, Pembelajaran Ekspositori, kemampuan menulis puisi

Abstract
This study aims to determine: The Effect of Cooperative Thinking Write (TTW) Type Learning Model Against the Poetry Writing Ability of Class VIII Students in Private Christian Middle School 3. This research is a quasi-experimental study. The population of this study was Class VIII students of Private Christian Middle School 3. The sample selection was done randomly by randomizing the class. The instrument used consisted of students' Poetry Writing Ability test. The results of the study showed that the average score of the poetry writing ability of students taught by the TTW learning model with the corrected average $\mathrm{Y}^{-}$(res) A1 $=28.84$ while the score of the students' poetry writing ability was taught by the expository learning model with an average corrected $\mathrm{Y}^{-}$(res) $\mathrm{A} 2=25.47$, while $\mathrm{t}$ table $=2.036$. because thitung abel $\mathrm{t}$ table then $\mathrm{H} 0$ is rejected. Thus it was concluded that there were differences in poetry writing abilities between students who were taught with TTW (A1) learning models and students who were taught with expository learning models (A2.

Keywords: TTW learning, Expository Learning, ability to write poetry

\section{PENDAHULUAN}

Menulis merupakan salah satu keterampilan yang berkaitan erat dengan keterampilan dasar terpenting pada manusia, yaitu berbahasa. menulis merupakan suatu keterampilan berbahasa yang digunakan untuk berkomunikasi secara tidak langsung, tidak secara tatap muka dengan orang lain. Hal ini mengandung pengertian bahwa dengan tulisan dapat membantu menjelaskan pikiran-pikiran kita melalui sebuah tulisan tanpa saling bertatap muka. Menulis merupakan suatu bentuk manifestasi kemampuan (keterampilan) berbahasa paling akhir dikuasai pelajar bahasa setelah kemampuan mendengarkan, berbicara, dan membaca (Nurgiyantoro, 2009: 296). Pembelajaran menulis puisi di sekolah merupakan bagian dari pembelajaran menulis sastra. Oleh karena itu, puisi sangat penting untuk diperhatikan dan diberikan kepada siswa. Karena di dalam pelajaran Bahasa Indonesia, sastra termasuk sebagai bahan yang harus diajarkan kepada siswa selain keterampilan berbahasa lainnya.

Kelancaran dan keberhasilan pelaksanaan proses pembelajaran Bahasa dan Sastra Indonesia sangat berpengaruh pada kreativitas masing-masing guru. Agar siswa terampil dalam menulis sebuah puisi, siswa harus paham dan mengerti benar tentang pengetahuan kebahasaan dan menguasai keterampilan berbahasa. Selain itu, siswa juga harus belajar untuk mengembangkan imajinasi mereka. Puisi dapat didefinisikan sebagai bentuk ekspresi seorang penulis dalam mengungkapkan emosi, imajinasi pemikiran, dan ide dalam susunan bahasa yang indah. Puisi merupakan karya emosi, imajinasi, pemikiran, ide, nada, irama, kesan panca indera, susunan kata, kata-kata kiasan, kepadatan, dan perasaan yang bercampur baur dengan memperhatikan pembaca. Senada dengan pendapat di atas, Pradopo (2002: 12) mengemukakan bahwa puisi itu mengekspresikan pemikiran yang membangkitkan perasaan yang 
merangsang imajinasi panca indera dalam susunan berirama yang diwujudkan lewat susunan kata yang mempunyai makna.

Keterampilan menulis puisi wajib dimiliki oleh siswa sebagai suatu keterampilan yang aktif dan produktif untuk mengungkapkan ide, pikiran, gagasan, pengetahuan, ilmu, dan pengalaman. Pentingnya latihan menulis puisi tidak hanya mempertajam pengamatan dan meningkatkan kemampuan bahasa, akan tetapi dengan latihan penulisan puisi siswa diharapkan dapat memperoleh minat segar yang muncul dari kedalaman puisi itu sendiri. Pembelajaran menulis puisi di sekolah bertujuan untuk menanamkan rasa peka terhadap karya sastra, sehingga memunculkan perasaan senang, cinta dan tertarik terhadap apresiasi sastra. Selain itu, pembelajaran menulis puisi di sekolah sangat penting dan bermanfaat bagi siswa karena dapat menstimulus otak sehingga siswa mampu berfikir kreatif dan simpatik terhadap lingkungan di sekitarnya.

Salah satu pembelajaran menulis sastra atau menulis kreatif sastra adalah menulis puisi. Menulis puisi merupakan sebuah kegiatan menulis kreatif karena dibutuhkan kreatifitas penulis untuk mengungkapkan perasaan mereka dalam sebuah puisi melalui tulisan. Perasaan yang diungkapkan penulis dalam sebuah puisi menggunakan bahasa yang figuratif dan terdapat pemadatan kata sehingga menimbulkan kesan ekspresif dan tidak meninggalkan kesan estetis. Kemampuan menulis puisi diajarkan kepada siswa agar bisa bersikap lebih kritis untuk menghadapi sebuah situasi. Siswa bisa memanfaatkan kemampuan menulisnya untuk menghasilkan sebuah karya yang ekspresif dan menarik untuk dibaca orang lain. Kemampuan menulis puisi diajarkan kepada siswa agar bisa bersikap lebih kritis untuk menghadapi sebuah situasi.

Fenomena yang dapat dilihat dari berbagai indikator kemampuan menulis, yang disebabkan proses pembelajaran yang masih konvensional, yakni kegiatan belajar mengajar didominasi oleh guru, sehingga mengakibatkan siswa kurang aktif di dalam kelas. Pembelajaran keterampilan menulis lebih banyak disajikan dalam bentuk teori-teori. Hal ini menyebabkan kurangnya kebiasaan menulis oleh siswa sehingga mereka sulit menuangkan ide-idenya dalam bentuk tulisan.

Kendala-kendala yang dihadapi siswa ketika sedang menulis puisi antara lain siswa sulit memunculkan dan mengembangkan ide, sulit mengekspresikan ide, pikiran, perasaan, dan imajinasi yang akan mereka tuangkan dalam puisi. Siswa mengalami kesulitan untuk menyesuaikan tema dengan isi puisi. Siswa juga mengemukakan tentang kesulitannya dalam menggunakan diksi, citraan dan gaya bahasa. Mereka kesulitan untuk menemukan pilihan kata yang tepat, citraan dan gaya bahasa yang sesuai dengan objek yang dihadapi, sehingga mereka merasa kurang maksimal dalam menulis puisi.

Untuk mengatasi masalah tersebut diperlukan model pembelajaran yang tepat. Menurut Sanjaya (2008: 76) model pembelajaran didefinisikan sebagai prosedur khusus untuk mengajarkan topik atau pelajaran tertentu yang harus memperhatikan empat faktor (kebijaksanaan terpilih) yaitu: pemilih materi dapat dilakukan oleh guru atau siswa; penyaji materi dapat perorangan, beregu, atau dipelajari sendiri; cara materi tersebut disajikan atau pendekatan misalkan dengan induktif, deduktif, analisis, sintesis, formal, non-formal, dan sebagainya; serta penerima materi (siswa) dapat secara perorangan, kelompok kecil, kelompok besar, kelompok heterogen, atau kelompok homogen. Suatu aktivitas yang diharapkan dapat diterapkan untuk menumbuhkembangkan kemampuan menulis siswa antara lain adalah dengan menerapkan model pembelajaran TTW adalah mengedepankan perlunya siswa mengkomunikasikan hasil pemikirannya yang diberikan guru.

Sebagai suatu prosedur khusus untuk mengajarkan konsep atau topik bahasa indonesia, model pembelajaran TTW mengurutkan langkah-langkah penerapannya seperti diuraikan oleh Trianto (2011: 78) adalah mula-mula siswa membaca dalam hati secara individual (think), kemudian siswa berdiskusi (talk) mengemukakan idenya dalam kelompok kecil, setelah itu siswa masing-masing merepresentasikan idenya dalam tulisan (write). Dengan model talk write (TTW) ini siswa menjadi tertarik untuk belajar. Bahkan lebih dari itu diharapkan siswa menjadi senang dan lebih memiliki ketertarikan sehingga kemampuan siswa dalam menulis puisi dapat meningkat lebih baik. Model talk write (TTW) diharapkan efektif dalam pembelajaran keterampilan siswa kelas VIII SMP Swasta Nasrani 3 Medan dalam menulis puisi sehingga siswa menjadi tertarik untuk belajar.

\section{METODOLOGI PENILAIAN}

\section{Jenis Penelitian}

Penelitian ini merupakan penelitian eksperimen semu (quasi eksperiment). Selain itu, pada quasi eksperimen juga tidak dapat dilakukan pengontrolan terhadap semua variabel luar yang mempengaruhi jalannya penelitian. Untuk subjek penelitian, pengelompokan dilalakukan berdasarkan kelompok yang telah terbentuk sebelumnya atau kelompok yang telah ada. Kelompok perlakuan ini disebut juga kelas eksperimen atau kelompok eksperimen. Suatu penelitian eksperimen, khususnya penelitian yang ingin menyelidiki keefektifan penggunaan metode mengajar baru, diperlukan kelas lain atau kelompok siswa yang menggunakan metode lama atau yang biasa dilakukan sebelumnya sebagai pembanding. Kelas 
pembanding ini disebut kelas kontrol. Hasil dari kelas kontrol ini akan menjadi pembanding dari kelas eksperimen untuk mengetahui apakah hasil kelas eksperimen lebih tinggi daripada kelas kontrol. Dengan kata lain, pada penelitian quasi eksperimen menggunakan kelas yang sudah ada.

\section{Tempat dan Waktu Penelitian}

Penelitian ini dilaksanakan di kelas VIII SMP Swasta Nasrani 3 Medan Tahun Pelajaran 2019/2020 dengan jadwal pelaksanaannya dikoordinasikan dengan kegiatan sekolah, tepatnya bulan Juli 2019. Adapun alasan pemilihan lokasi ini dipilih sebagai tempat penelitian dengan pertimbangan sebagai berikut : 1) rendahnya kemampuan dalam menulis puisi siswa pada pembelajaran menulis puisi, 2) pembelajaran menulis puisi di VIII SMP Swasta Nasrani 3 Medan selama ini masih menggunakan model pembelajaran konvensional, 3) belum adanya penelitian yang sejenis baik masalah maupun tujuan yang akan akan dicapai dengan penelitian ini, dan 4) adanya keterbukaan dari pihak sekolah untuk merespon keinginan dari penulis untuk melakukan penelitian sekaligus memberikan contoh pembelajaran yang inovatif.

\section{Populasi dan Sampel Penelitian}

Sumber data dalam penelitian kuantitatif adalah dengan menentukan populasi dan sampel. Populasi penelitian ini adalah seluruh siswa VIII SMP Swasta Nasrani 3 Medan yang terdiri dari 3 kelas dengan jumlah 95 siswa. Karakteristik siswa tersebar dalam 3 kelas tersebut tidak dikelompokkan atas ranking ujian masuk maupun pengelompokan kelas unggulan, tetapi penyebaran siswa ke dalam 3 kelas tersebut secara acak sewaktu penempatan siswa dalam kelompok kelas masing-masing. Dari 3 kelas yang terpilih secara acak 2 kelas yaitu Kelas VIII-1,VIII-2, masing-masing 32 siswa sebagai sampel penelitian. Kelompok eksperimen dibagi menjadi dua kelompok-kelompok kecil yang anggota kelompoknya heterogen. Terdiri dari siswa pandai, sedang, dan lemah. Penentuan siswa-siswa ini didasarkan dari informasi guru dan nilai yang mereka peroleh sebelumnya.

\section{HASIL dan PEMBAHASAN PENELITIAN}

\section{A. Hasil Penelitian}

Berikut ini disajikan distribusi data penelitian yang meliputi skor tes kelompok siswa yang dibelajarkan dengan model pembelajaran TTW $\left(\mathrm{A}_{1}\right)$, (2) yang dibelajarkan dengan model pembelajaran ekspositori $\left(\mathrm{A}_{2}\right)$. Sebelum dilaksanakannya penelitian terlebih dahulu dilakukan Pengujian validitas instrumen pretes kemampuan menulis puisi siswa digunakan rumus Product Moment dan untuk menguji reliabilitas skor pretes kemampuan menulis puisi siswa digunakan rumus Alpha Cronbach, pada taraf $\alpha$ $=0,05$. Pengujian validitas soal terhadap 10 butir instrumen yang terdapat 10 butir instrumen yang valid. Data lengkap rangkuman skor kemampuan menulis puisi siswa untuk masing-masing kelompok disajikan pada tabel 1 .

Tabel 1 Data Skor Kemampuan Menulis Puisi Siswa

\begin{tabular}{|l|l|r|r|}
\hline \multicolumn{3}{|c|}{ Statistics } \\
\hline \multirow{2}{*}{$\mathrm{N}$} & Valid & $\mathrm{X}$ & $\mathrm{Y}$ \\
\cline { 2 - 4 } & Missing & 32 & 32 \\
\hline Mean & 0 & 0 \\
\hline Std. Error of Mean & 28,84 & 25,47 \\
\hline Median & 0,753 & 0,936 \\
\hline Mode & 29,00 & 25,00 \\
\hline Std. Deviation & 29 & 24 \\
\hline Variance & 4,259 & 5,298 \\
\hline Range & 18,136 & 28,064 \\
\hline Minimum & 17 & 20 \\
\hline Maximum & 20 & 16 \\
\hline Sum & 37 & 36 \\
\hline
\end{tabular}

\section{Kemampuan Menulis Puisi Siswa yang Dibelajarkan dengan Model Pembelajaran TTW (A1)}

Data kemampuan menulis puisi siswa yang dibelajarkan dengan model pembelajaran TTW pada tabel 2 menunjukkan bahwa skor tertinggi 32, skor terendah 20, skor rata-rata 28,84, standart deviasi 4,259 dengan modus 29 dan median 29. Distribusi frekuensi skor kemampuan menulis puisi yang menggunakan model pembelajaran TTW disajikan pada tabel 2. 
Tabel 2 Distribusi Frekuensi Skor Kemampuan Menulis Puisi Siswa yang Dibelajarkan dengan Model Pembelajaran TTW (A $\left.\mathbf{A}_{1}\right)$

\begin{tabular}{|c|c|c|c|c|}
\hline No. & Kelas Interval & $\begin{array}{c}\text { Frekuensi } \\
\text { Absolut }\end{array}$ & $\begin{array}{c}\text { Frekuensi } \\
\text { Relatif \% }\end{array}$ & $\begin{array}{c}\text { Frekuensi } \\
\text { Kumulatif \% }\end{array}$ \\
\hline $\mathbf{1}$ & $20-22$ & 3 & 9,38 & 9,38 \\
\hline $\mathbf{2}$ & $23-25$ & 4 & 12,50 & 21,90 \\
\hline $\mathbf{3}$ & $26-28$ & 7 & 21,90 & 43,80 \\
\hline $\mathbf{4}$ & $29-31$ & 9 & 28,10 & 71,90 \\
\hline $\mathbf{5}$ & $32-34$ & 6 & 18,80 & 90,60 \\
\hline $\mathbf{6}$ & $35-37$ & 3 & 9,38 & 100,00 \\
\hline & Jumlah & $\mathbf{3 2}$ & $\mathbf{1 0 0}$ & $\mathbf{1 0 0}$ \\
\hline
\end{tabular}

Berdasarkan tabel 2, dapat dijelaskan bahwa kemampuan menulis puisi siswa yang dibelajarkan dengan model pembelajaran TTW, 7 siswa (21,88\%) mempunyai kemampuan menulis di bawah skor rata-rata, 7 siswa $(21,88 \%)$ berada pada skor rata-rata, dan 18 siswa $(56,25 \%)$ mempunyai kemampuan menulis puisi di atas skor rata-rata.

2. Kemampuan Menulis Puisi Siswa yang Dibelajarkan dengan Model Pembelajaran Ekspositori (A2)

Data kemampuan menulis puisi siswa yang dibelajarkan dengan model pembelajaran ekspositori $\left(\mathrm{A}_{2}\right)$ pada tabel 3, menunjukkan bahwa skor tertinggi adalah 36, skor terendah 16, skor rata-rata 25,47, standart deviasi 5,298 dengan modus 24 dan median 25. Distribusi frekuensi skor kemampuan menulis puisi siswa yang dibelajarkan dengan model pembelajaran ekspositori disajikan pada tabel 3.

Tabel 3 Distribusi Frekuensi Skor Kemampuan Menulis Puisi Siswa yang Dibelajarkan dengan Model Pembelajaran Ekspositori (A)

\begin{tabular}{|c|c|c|c|c|}
\hline No. & Kelas Interval & $\begin{array}{c}\text { Frekuensi } \\
\text { Absolut }\end{array}$ & $\begin{array}{c}\text { Frekuensi } \\
\text { Relatif } \%\end{array}$ & $\begin{array}{c}\text { Frekuensi } \\
\text { Kumulatif \% }\end{array}$ \\
\hline $\mathbf{1}$ & $16-19$ & 4 & 12,50 & 12,50 \\
\hline $\mathbf{2}$ & $20-23$ & 8 & 25,00 & 37,50 \\
\hline $\mathbf{3}$ & $24-27$ & 9 & 28,13 & 65,63 \\
\hline $\mathbf{4}$ & $28-31$ & 6 & 18,75 & 84,38 \\
\hline $\mathbf{5}$ & $32-35$ & 4 & 12,50 & 96,88 \\
\hline $\mathbf{6}$ & $36-39$ & 1 & 3,16 & 100,00 \\
\hline & Jumlah & $\mathbf{3 2}$ & $\mathbf{1 0 0}$ & $\mathbf{1 0 0}$ \\
\hline
\end{tabular}

Berdasarkan tabel 3, dapat dijelaskan bahwa kemampuan menulis puisi siswa yang dibelajarkan dengan model pembelajaran ekspositori, 12 siswa (37,50\%) mempunyai kemampuan menulis puisi di bawah skor rata-rata, 9 siswa $(28,13 \%)$ mempunyai kemampuan menulis puisi yang berada pada skor rata-rata, dan 11 siswa $(34,38 \%)$ mempunyai kemampuan menulis puisi di atas skor rata-rata.

\section{Pengujian Persyaratan Analisis}

Uji persyaratan data yang dianalisis dengan menggunakan uji t adalah (1) uji normalitas; (2) uji homogenitas varians yang terdiri dari uji antar kelompok.

\section{Uji Normalitas Data}

Pengujian normalitas data sampel dilakukan dengan menggunakan uji Liliefors. Hipotesis yang akan diuji normalitasnya adalah:

$\mathrm{H}_{0}$ : data berasal dari populasi yang berdistribusi normal

$\mathrm{H}_{1}$ : data berasal dari populasi yang tidak berdistribusi normal

Kriteria pengujian adalah menerima hipotesis nol $\left(\mathrm{H}_{0}\right)$, bila Lhitung $\leq \mathrm{L}_{\text {tabel }}$, dan sebaliknya bila $\mathrm{L}_{\text {hitung }}>\mathrm{L}_{\text {tabel }}$, maka hipotesis nol $\left(\mathrm{H}_{0}\right)$ ditolak pada $\alpha=0,05$.

Tabel 4 Rangkuman Hasil Perhitungan Uji Normalitas

\begin{tabular}{|l|l|c|c|c|c|}
\hline No. & \multicolumn{1}{|c|}{ Kelompok Sampel } & N & Lhitungsig & Lsig $_{\text {Ket }}$ & Normal \\
\hline 1 & $\begin{array}{l}\text { Skor Kemampuan Menulis Puisi Siswa } \\
\text { yang Diajarkan dengan menggunakan }\end{array}$ & 32 & 0,200 & 0,05 & Normal \\
\hline 2 & $\begin{array}{l}\text { Sembelajaran TTW } \\
\text { yang Diajarkan dengan menggunakan } \\
\text { Pembelajaran Ekspositori }\end{array}$ & 32 & 0,200 & 0,05 & \\
\hline
\end{tabular}


Tabel 4 menunjukkan bahwa semua kelompok kemampuan menulis puisi yang diuji dengan menggunakan uji Lilliefors, memberikan nilai Sig lebih besar pada $\alpha=0,05$. Dengan demikian dikatahui bahwa semua kelompok data berdistribusi normal. Berdasarkan hal itu dapat disimpulkan bahwa seluruh data kemampuan menulis puisi dalam penelitian ini bersumber dari populasi yang berdistribusi normal. Dengan demikian persyaratan kenormalan data dapat terpenuhi dan dapat dilakukan analisis lanjut yaitu analisis varians.

\section{Uji Homogenitas Varians}

Uji homogenitas data dilakukan dengan teknik Uji F untuk uji homogenitas kelompok sampel. Pengujian homogenitas varians dilakukan melalui pemeriksaan terhadap varians skor kemampuan menulis puisi. Pengujian homogenitas bertujuan untuk mengetahui varians bersifat homogen atau tidak. Perhitungan pengujian homogenitas dilakukan dengan menggunakan uji harley. Hasil uji homogenitas untuk semua kelompok sampel diperoleh dari skor postes adalah $\mathrm{F}$ hitung $=1,24<\mathrm{F}$ tabel $(2,07)$, dengan demikian dapat disimpulkan bahwa populasi penelitian ini bersifat homogen.

\section{Pengujian Hipotesis}

Pengujian hipotesis dalam penelitian ini berkaitan dengan pengaruh utama (main effect) variabel bebas, yaitu model pembelajaran TTW dan model pembelajaran ekspositori. Bahwa kemampuan menulis puisi siswa yang dibelajarkan dengan model pembelajaran TTW lebih tinggi daripada kemampuan menulis puisi siswa yang dibelajarkan dengan model pembelajaran ekspositori. Teknik analisis yang digunakan dalam pengujian hipotesis penelitian adalah Uji t. Hasil perhitungan dengan t disajikan pada Tabel 5 .

Tabel 5 Rangkuman Uji Hipotesis dengan uji t

\begin{tabular}{|c|c|c|c|c|c|c|c|c|}
\hline \multicolumn{9}{|c|}{ Independent Samples Test } \\
\hline & & \multicolumn{2}{|c|}{$\begin{array}{c}\text { Levene's Test } \\
\text { for Equality of } \\
\text { Variances }\end{array}$} & \multicolumn{5}{|c|}{ t-test for Equality of Means } \\
\hline & & \multirow[b]{2}{*}{$\mathrm{F}$} & \multirow[b]{2}{*}{ Sig. } & \multirow[b]{2}{*}{$\mathrm{t}$} & \multirow[b]{2}{*}{ df } & \multirow{2}{*}{$\begin{array}{l}\text { Sig. (2- } \\
\text { tailed) }\end{array}$} & \multicolumn{2}{|c|}{$\begin{array}{c}\text { 95\% Confidence } \\
\text { Interval of the } \\
\text { Difference }\end{array}$} \\
\hline & & & & & & & Lower & Upper \\
\hline \multirow[t]{2}{*}{ SKOR } & $\begin{array}{l}\text { Equal } \\
\text { variances } \\
\text { assumed }\end{array}$ & 1,871 & 0,176 & 2,809 & 62 & 0,007 & 0,973 & 5,777 \\
\hline & $\begin{array}{l}\text { Equal } \\
\text { variances } \\
\text { not } \\
\text { assumed }\end{array}$ & & & 2,809 & 59,264 & 0,007 & 0,971 & 5,779 \\
\hline
\end{tabular}

Hasil perhitungan dari tabel di atas menunjukkan simpulan, yaitu Untuk menguji hipotesis di atas di uji dengan menggunakan uji t. Hasil perhitungan uji t kemampuan menulis puisi siswa adalah 2.809, sedangkan $t_{\text {tabel }}=2.036$. karena $t_{\text {hitung }}>\mathrm{t}_{\text {tabel }}$ maka $\mathrm{H}_{0}$ ditolak. Artinya Siswa yang mengikuti Pembelajaran TTW berpengaruh terhadap kemampuan menulis puisi siswa bila dibandingkan dengan siswa yang mengikuti Pembelajaran Ekspositori. Jadi, dapat disimpulkan bahwa kemampuan menulis puisi siswa yang dibelajarkan dengan model pembelajaran TTW lebih tinggi daripada kemampuan menulis puisi siswa yang dibelajarkan dengan model pembelajaran ekspositori.

\section{B. Pembahasan}

Temuan penelitian ini disajikan untuk menjawab permasalahan dalam penelitian ini. Berdasarkan perhitungan kemampuan menulis puisi siswa adalah 2.809, sedangkan $t_{\text {tabel }}=2.036$. karena $t_{\text {hitung }}>t_{\text {tabel }}$ maka $\mathrm{H}_{0}$ ditolak. Dengan demikian disimpulkan bahwa terdapat perbedaan kemampuan menulis puisi antara siswa yang dibelajarkan dengan model pembelajaran TTW $\left(\mathrm{A}_{1}\right)$ dan siswa yang dibelajarkan dengan model pembelajaran ekspositori $\left(\mathrm{A}_{2}\right)$. Hal ini berarti bahwa besarnya nilai $\mathrm{F}_{\text {hitung }}$ yang dihasilkan dalam pengujian hipotesis ini murni berasal dari efek perlakukan (treatment) model pembelajaran TTW yang diberikan kepada siswa.

Hal ini sesuai dengan skor kemampuan menulis puisi siswa yang dibelajarkan dengan model pembelajaran TTW dengan rata-rata dikoreksi $\bar{Y}_{(\mathrm{res}) \mathrm{A} 1}=28,84$ sedangkan skor kemampuan menulis puisi siswa yang dibelajarkan dengan model pembelajaran ekspositori dengan rata-rata dikoreksi $\bar{Y}_{(\text {res }) \mathrm{A} 2}=$ 25,47 . Hasil perhitungan menunjukkan bahwa kemampuan menulis puisi siswa yang dibelajarkan dengan model pembelajaran TTW lebih tinggi dibandingkan dengan kemampuan menulis puisi siswa yang dibelajarkan dengan model pembelajaran ekspositori. Dengan demikian pembelajaran dengan model 
pembelajaran TTW yang dilakukan dalam penelitian ini dapat meningkatkan kemampuan menulis puisi yang lebih baik dibanding dengan pembelajaran dengan model pembelajaran ekspositori. Temuan ini sekaligus menjawab hipotesis penelitian bahwa kemampuan menulis puisi siswa yang dibelajarkan dengan model pembelajaran TTW lebih tinggi daripada siswa yang dibelajarkan dengan model pembelajaran ekspositori.

Pembuktian hipotesis berdasarkan kajian empiris yang dilakukan peneliti didukung oleh teori dan konsep yang dikemukakan oleh pakar seperti yang dikutip bahwa model pembelajaran TTW adalah model pembelajaran yang menekankan proses kerja sama melalui berpikir secara individual dan berdiskusi kelompok untuk memperoleh berbagai pengetahuan yang berguna bagi setiap siswa dalam upayanya menulis tentang suatu masalah.

Huda (2014:68) menyatakan, Model pembelajaran TTW memiliki beberapa kelebihan, yaitu menciptakan suasana belajar yang menyenangkan, dan bermakna dari hasil mengamati dan menyimpulkan, meningkatkan minat dan partisipasi siswa, serta meningkatkan pemahaman dan daya ingat melalui hasil karya tulis. Berdasarkan pendapat ini, dapat dinyatakan bahwa selain dapat mewujudkan suasana belajar yang menyenangkan, penggunaan model pembelajaran TTW dapat lebih efektif untuk meningkatkan kemampuan menulis puisi siswa daripada penggunaan model pembelajaran ekspositori. Dalam pembelajaran yang menggunakan model pembelajaran TTW ada kegiatan berpikir (think) baik untuk memahami penulisan puisi maupun untuk memahami tema sebagai tantangannya untuk dapat menghasilkan gagasan-gagasannya secara kreatif. Selain itu, dalam penggunaan model pembelajaran TTW ada kegiatan berdiskusi yang dapat memperluas wawasan siswa tentang tema dan dapat menjadi sumber inspirasi bagi siswa dalam melahirkan gagasan-gagasannya beserta fakta-fakta pendukungnya. Peluang untuk beraktivitas kreatif seperti itu tidak terdapat dalam penggunaan model pembelajaran ekspositori.

Siswa yang relatif lemah kemampuan pemahamannya dan yang mengalami kesulitan dalam belajar, terbantu dengan penggunaan model pembelajaran TTW. Kurniawan (2018:54) menyatakan, "Through this model, students can express their thoughts, exchange opinions, cooperate with each other if there are friends in the group who have difficulty." Artinya, melalui model ini, siswa dapat menyampaikan pikiran mereka, bertukar pendapat, bekerja sama dengan siswa lain jika ada teman-teman dalam kelompok yang mengalami kesulitan.

Dengan demikian model pembelajaran TTW banyak manfaatnya. Selain manfaatnya yang disampaikan oleh para ahli, model pembelajaran ini dapat digunakan untuk meningkatkan kemampuan menulis puisi siswa dengan lebih efektif, dapat membantu siswa yang relatif lemah kemampuan pemahamannya, dapat membantu siswa yang mengalami kesulitan dalam belajar, dapat meningkatkan pemanfaatan kemampuan berpikir kreatif dalam menulis, dan dapat meningkatkan kemampuan berpikir kreatif siswa.

Oleh karena itu, dapat disimpulkan bahwa penggunaan model pembelajaran TTW dapat menjadikan pembelajaran menulis puisi menjadi lebih baik dan menyenangkan serta dapat meningkatkan daya kreatif siswa. Berdasarkan uraian di atas, dapat disimpulkan bahwa dalam merencanakan program pembelajaran menulis puisi, khususnya dalam memilih model pembelajaran, kemampuan menulis puisi siswa perlu dipertimbangkan. Untuk siswa yang memiliki kemampuan menulis puisi rendah, model pembelajaran TTW adalah model pembelajaran yang lebih relevan dalam pembelajaran menulis puisi.

\section{Keterbatasan Penelitian}

Penelitian telah dilakukan sebaik mungkin. Hal ini dilakukan agar dapat diperoleh hasil penelitian yang benar-benar merupakan efek perlakuan yang diberikan. Namun, pelaksanaan penelitian ini tidak terlepas dari kekurangan dan kelemahan karena hal-hal yang tidak dapat dikontrol dan dihindari. Kelemahan yang dirasakan selama melakukan penelitian ini adalah sebagai berikut.

1. Pengaruh kegiatan pembelajaran lain yang dapat mengganggu siswa untuk berkonsentrasi dalam pelaksanaan perlakuan, misalnya tugas mandiri dan tugas kelompok yang harus dikerjakan dan dipertanggung jawabkan, tidak dapat dikontrol. Oleh karena itu, hasil penelitian perlu ditafsirkan dengan hati-hati.

2. Penelitian ini terbatas pada perlakuan dengan model pembelajaran TTW dan ekspositori. Padahal, masih banyak faktor lain yang berpengaruh terhadap kemampuan menulis puisi siswa, misalnya model-model pembelajaran lain, minat belajar, motivasi belajar, dan sebagainya.

3. Subjek dari sampel penelitian ini hanya berasal dari SMP Swasta Nasrani 3 Medan, sehingga hasil penelitian belum tentu sesuai dengan sekolah lain atau daerah lain yang memiliki karakteristik yang berbeda. 


\section{SIMPULAN dan SARAN \\ Simpulan}

Berdasarkan hasil penelitian dan pembahasan tentang pengaruh model pembelajaran kemampuan menulis puisi pada siswa, disimpulkan sebagai berikut: Kemampuan menulis puisi siswa yang dibelajarkan dengan model pembelajaran TTW lebih tinggi daripada kemampuan menulis puisi siswa yang dibelajarkan dengan model pembelajaran ekspositori. Oleh karena itu, model pembelajaran TTW lebih relevan digunakan dalam pembelajaran menulis puisi.

\section{Saran}

Hasil penelitian menunjukkan bahwa bagi siswa yang memiliki kemampuan menulis puisi siswa yang dibelajarkan dengan model pembelajaran TTW lebih tinggi daripada kemampuan menulis puisi siswa yang dibelajarkan dengan model pembelajaran ekspositori. Hal ini menunjukkan bahwa bagi siswa yang memiliki kemampuan lebih relevan dibelajarkan dengan model pembelajaran TTW. Oleh karena itu, guru perlu mempertimbangkan pemilihan model pembelajaran yang relevan dengan kemampuan siswanya dalam perencanaan pembelajaran menulis puisi. Untuk siswa hendaknya memilih dan menggunakan model pembelajaran TTW.

\section{DAFTAR PUSTAKA}

Akhadiah, Sabarti. (2003). Pembinaan Kemampuan Menulis Bahasa Indonesia. Jakarta: Erlangga.

Depdiknas. (2003). Panduan Penyusunan Kurikulum Tingkat Satuan Pendidikan Jenjang Pendidikan Dasar dan Menengah, Standar Isi, Standar Kelulusan. Depdiknas, Jakarta.

Huda, M. (2014). Model-model Pengajaran dan Pembelajaran : Isu-isu Metodis dan Paradigmatis. Yogyakarta: Pustaka Pelajar.

Ifiah dan Santosa, Yunarko Budi. (2009). Pengajaran Puisi: Sebuah Penelitian Tindakan Kelas. Yogyakarta: Pustaka Pelajar.

Kurniawan, L.A. (2014). "Pengoptimalan Blog dalam Upaya Menunjang Keterampilan Menulis Mahasiswa" dalam Jurnal Sasindo Vol.2 Nomor 1 (Juli 2014), h.61.

Muhibbin. (2003). Psikologi pendidikan, Bandung: Rosdakarya.

Nurgiyantoro, Burhan, Gunawan, Marzuki. (2009). Statistik Terapan untuk Penelitian Ilmu-ilmu Sosial. Yogyakarta: Gadjah Mada University Press.

Sanjaya, W. (2008). Strategi Pembelajaran Berorientasi Standar Proses Pendidikan. Jakarta: Kencana Prenada Media Group.

Sudjana. (2005). Metoda Statistika. Bandung: Tarsito

Sugiyono. (2008). Metode Penelitian Pendidikan : Pendekatan Kuantitatif, Kualitatif, dan $R \& D$. Bandung: Alfabeta.

Sukino, (2010). Menulis Itu Mudah. . Pustaka Populer: Yogyakarta.

Trianto. (2011). Mendesain Model Pembelajaran Inovatif-Progresif. Jakarta: Kencana Prenada Media Group.

Pradopo, Rachmat Djoko. 2002. Kritik sastra Modern. Yogyakarta: Gama Media. 